\title{
Industrial Tree Plantations and the Land Rush in China
}

This book analyses the political and economic causes, mechanisms and impacts of the industrial tree plantation boom in China.

In the past two decades, the industrial tree plantation sector has been expanding rapidly in China, especially in Guangxi Province. Based on extensive primary data, this book concentrates on the political economy of the sector's expansion with a focus on the recent and dramatic agrarian transformation involving the land-labour nexus, the impact on villagers' livelihoods, the role of the state, and political reactions from below. The book questions the stereotypical portrayal of local communities as the excluded villager. Instead, it demonstrates that this is a much more complex issue with varying levels of passive and active forms of inclusion and exclusion within local communities. While most literature focuses on crop booms for food and biofuel production the industrial plantation sector has largely been overlooked, despite it being one of the biggest sectors in the current rush for land. Filling this lacuna, this book also reveals that while China has traditionally been painted as a major land grabber and consumer of crop booms it is also a destination of foreign investment. In doing so the book highlights how large-scale foreign land deals can also take place in traditional 'grabber' countries like China which feeds into the wider debates about global land politics and resource grabbing.

This book will be of great interest to students and scholars of land grabbing, rural development and agrarian transformations, as well as Chinese development.

Yunan Xu is a Post-doctoral researcher at the International Institute of Social Studies (ISS, The Hague) of Erasmus University Rotterdam. She works for a European Research Council (ERC) Advanced Grant awarded project "Commodity \& Land Rushes and Regimes: Reshaping Five Spheres of Global Social Life (RRUSHES-5)". She obtained her PhD degree in development studies at ISS. Her research experience and interest revolve around land politics and commodity rush, and how these have shaped the politics of local natural resource control, food, as well as labour and livelihoods, with the geographic areas both in China and beyond (including the countries involved in the Belt and Road Initiative). She has published in top international academic journals, including Journal of Peasant Studies, Geoforum, Land use policy, Journal of Cleaner Production, Third World Quarterly and Third World Thematics. 


\section{Routledge Studies in Global Land and Resource Grabbing}

Edited by Andreas Neef and Chanrith Ngin, The University of Auckland, New Zealand

This series presents and discusses 'resource grabbing' research in a holistic manner by addressing how the rush for land and other natural resources (water, forests, minerals, etc.) is intertwined with agriculture, mining, tourism, energy, carbon markets, climate change, and disasters. This series welcomes contributions from a wide range of inter-disciplinary approaches and on a global basis

Titles in this series include:

\section{Industrial Tree Plantations and the Land Rush in China} Implications for Global Land Grabbing Yunan Xu

For more information about this series, please visit: https://www.routledge.com/ sustainability/series/GLRG 


\section{Industrial Tree Plantations and the Land Rush in China}

Implications for Global Land Grabbing

\section{Yunan Xu}

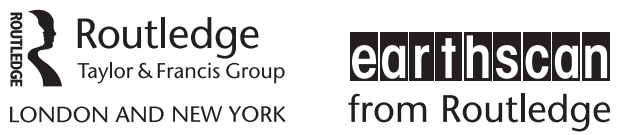


First published 2020

by Routledge

2 Park Square, Milton Park, Abingdon, Oxon OX14 4RN

and by Routledge

52 Vanderbilt Avenue, New York, NY 10017

Routledge is an imprint of the Taylor $\mathbb{E}$ Francis Group, an informa business

(c) 2020 Yunan Xu

The right of Yunan Xu to be identified as author of this work has been asserted by her in accordance with sections 77 and 78 of the Copyright, Designs and Patents Act 1988.

All rights reserved. No part of this book may be reprinted or reproduced or utilised in any form or by any electronic, mechanical, or other means, now known or hereafter invented, including photocopying and recording, or in any information storage or retrieval system, without permission in writing from the publishers.

Trademark notice: Product or corporate names may be trademarks or registered trademarks, and are used only for identification and explanation without intent to infringe.

British Library Cataloguing-in-Publication Data

A catalogue record for this book is available from the British Library

Library of Congress Cataloging-in-Publication Data

Names: Xu, Yunan, author.

Title: Industrial tree plantations and the land rush in China :

implications for global land grabbing / Yunan Xu.

Description: Abingdon, Oxon ; New York, NY : Routledge, 2020.

Series: Routledge studies in global land and resource grabbing |

Includes bibliographical references and index.

Identifiers: LCCN 2019051229 (print) | LCCN 2019051230 (ebook)

Subjects: LCSH: Forest products industry-China. |

Tree farms-Economic aspects_China. | Land use-China. |

Investments, Foreign-China.

Classification: LCC HD9766.C52 .X82 2020 (print) |

LCC HD9766.C52 (ebook) | DDC 338.1/40951—dc23

LC record available at https://lccn.loc.gov/2019051229

LC ebook record available at https://lccn.loc.gov/2019051230

ISBN: 978-0-367-42909-6 (hbk)

ISBN: 978-1-003-00089-1 (ebk)

Typeset in Goudy

by codeMantra 
To my dear parents and Fengfeng 此书献给我亲爱的父母和风风 

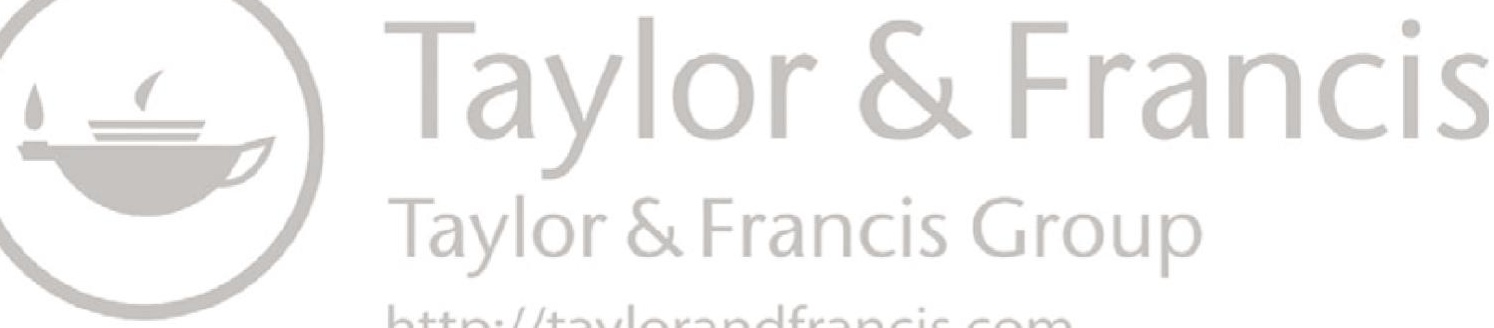

http://taylorandfrancis.com 


\section{Contents}

List of illustrations $\quad$ ix

Acknowledgements xi

List of acronyms and abbreviations xiii

1 Rethinking the industrial tree plantation sector in Southern China 1

2 The rise of the ITP sector in Southern China 61

3 The role of the state in the expansion of the ITP sector in China

4 Foreign investments and their land access in the industrial tree plantation sector

5 Changes in villagers' livelihoods in Southern China within the rise of ITP sector

6 The politics of inclusion and exclusion in the emerging industrial tree plantation sector in China

7 Conclusion 161

$\begin{array}{ll}\text { Appendix } & 171\end{array}$

Index 183 

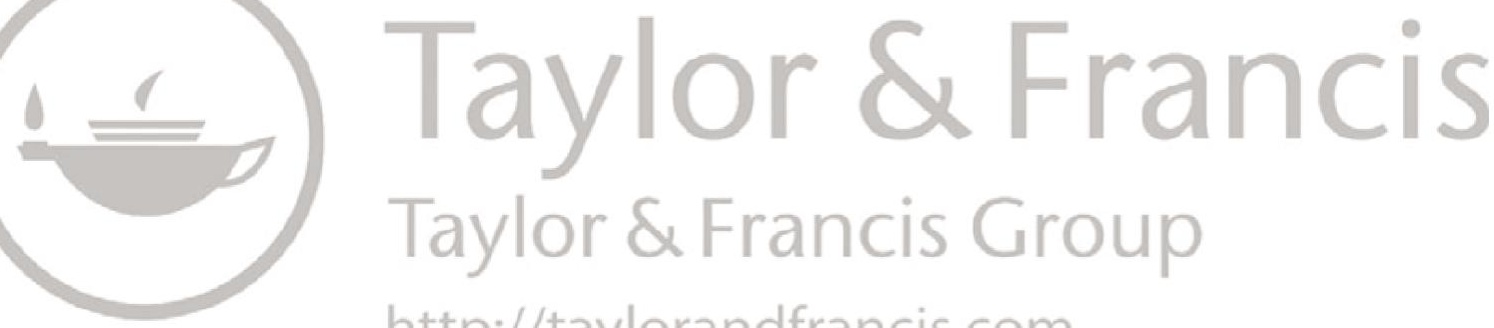

http://taylorandfrancis.com 


\section{Illustrations}

\section{Figures}

1.1 Accumulation schemes within the rise of the ITP sector in Southern China

1.2 Contiguous forestland for ITPs 8

1.3 Small plots of eucalyptus trees remained in farmland in Guangxi 11

1.4 The map of Guangxi 13

1.5 Research problem structure 15

1.6 The multiple uses of ITPs 20

1.7 Rough sketch of different plots of land allocated to household under HRS

1.8 Key actors in the ITP sector in Southern China 30

1.9 Schema on how key concepts link to one another 34

1.10 Visited sites in 2015

1.11 Fieldwork visited sites in 2016

2.1 Regional plantation areas and their increase between the years 1990 and 2015 (million ha)

2.2 Area of eucalyptus trees in Guangxi (1,000 ha)

2.3 Domestic consumption and production of forest products in China (million $\mathrm{m}^{3}$ )

2.4 The Chinese import volumes of fibreboards $\left(1,000 \mathrm{~m}^{3}\right)$, wood-based panels $\left(1,000 \mathrm{~m}^{3}\right)$ and pulp for paper (1,000 tonnes) 65

2.5 Land-use in Guangxi 66

2.6 Fragmented paddy land 68

2.7 The intertwined factors for the rise of the ITP sector 74

3.1 The bureaucracy 80

3.2 Da Huanghou timber processing industrial park in Wuming County 86

3.3 The newly planted pine trees and Castanopsis hystrix trees on the forestland of a state-owned farm 90

5.1 Percentage share of wages in total income of average rural household in Guangxi 118

5.2 A plot near ITPs in Binyang County in Guangxi 120

5.3 Eucalyptus trees planted by an "intimate land grabber" (top photo) and by Stora Enso (bottom photo) 


\section{$\mathrm{x} \quad$ Illustrations}

5.4 A land plot tilled to change land-use from eucalyptus trees to sugarcane

6.1 Typology of villagers' positions

6.2 Villagers' grievances towards land and environmental issues 149

7.1 Typology of land-use change with the rise of the ITP sector 163

7.2 Labour flow during the rise of the ITP sector

\section{Tables}

1.1 The area of Chinese "planted forest" (/plantation) in 1990, 2010, ITPs in the 1980s (thousand ha)

1.2 The characteristics of the ITP sector

1.3 Data collection methods

1.4 General information on visited sites in 2015

1.5 General information on informants during fieldwork in $2015 \quad 42$

1.6 General information on visited villages in $2016 \quad 45$

1.7 Summary of the interviewees in $2016 \quad 46$

2.1 Property rights of forestland in Guangxi (in 2010) 69

3.1 The variegated attitudes of the local state towards the ITP sector 91

4.1 Two main foreign investors in Guangxi 97

5.1 Three main alternative livelihood changes by villagers in Guangxi 122

5.2 Distinct channels of individual villager-dominated land grabbing 123

6.1 Villagers' attitudes towards the economic value of the ITP sector 141

6.2 Different types of villagers' perceptions of the economic value 148

6.3 Villagers' different political reactions to the rise of the ITP sector 152

7.1 Typology of the change in land control around the ITP sector in Guangxi 


\section{Acknowledgements}

This work is adapted from my PhD dissertation. It was made possible with the support and help of many people.

First and foremost, my deepest and heartfelt thanks to my three $\mathrm{PhD}$ supervisors, Professor Max Spoor, Professor Jun Borras, and Dr Mindi Schneider, for their guidance and support throughout my $\mathrm{PhD}$ journey. I would like to express my special thanks to Jun. He guided me to the world of critical agrarian studies, helped me to deal with various challenges, and taught me how to be a good scholar (though I am still on the way). His smart and critical thinking, hardworking passion for research and life, and deep love for peasants really inspire and motivate me. Without his generous support, I would not have been able to finish my $\mathrm{PhD}$ and this book. I can never thank him enough. To Max, I am extremely grateful. He has offered me enormous support at every stage of my $\mathrm{PhD}$. He was always kind and encouraging. His mentorship was crucial to the completion of this work. I also owe many thanks to Mindi. Her insightful comments and suggestions have profoundly sharpened this work. She was always patient, stimulating, and constructive in her supervision. I tremendously benefitted from discussions with her. And her dedication to Chinese agrarian studies as a female scholar is an inspiration.

Moreover, I would like to express my deepest gratitude to those who have kindly provided critical and constructive comments and suggestions that helped improve this work. Thanks to all my committee members in my $\mathrm{PhD}$ seminars: namely, Professor Jan Douwe van der Ploeg, Professor Murat Arsel, Dr Alberto Alonso-Fradejas, Professor Ye Jingzhong, Dr Julien-François Gerber and Clara MiYong Park, Professor Annelies Zoomers and Dr Georgina Gomez. Also, thanks to three anonymous reviewers of my book proposal.

Furthermore, I am deeply grateful to those who helped, supported, and facilitated my fieldwork in Southern China in many ways. Special thanks to Professor Ye for his advice and support throughout the process. Many thanks to my friends and colleagues: Wang Chunyu, Hu Zhen, Li Hua, and Liu Juan for their support, dedication, and company during part of my fieldwork. I am also greatly indebted to communities that I visited in Guangxi and Yunnan, particularly those villagers who shared their stories and thoughts with me. All their support made my research possible. 


\section{xii Acknowledgements}

I am also sincerely thankful for the support I received from my comrades and friends. Special thanks to Natalia, Daniela, Elyse, Christina, Ratha, Alberto, Tsegaye, Ben, Salena, Zoe, Laura, Cecile, Sergio, Arnim, Yukari, Amod, Antonio, Eric, Natacha, Nguyet, Martha, Jin, Sara, Clara, Mads, Nadine, Donna, Adwoa, Boa, Umut, Juan, Li Hua, Hu Zhen, and the other fellow 'villagers' at ISS. Discussing, debating, and chatting with them immensely inspired me to complete and sharpen this work. Special thanks to Natalia, Christina, Laura, Tsegaye, Sue, and Salena for their help in revising my research papers, which are part of this work. Special thanks as well to the friends I met during courses, seminars, and conferences from different parts of the world for their insights and questions. Many thanks to the editors and all other staff members of Routledge for their effort in bringing this book out.

Thanks to China Scholarship Council (CSC) for the financial support for four years' research in the Netherlands. And also, thanks to BRICS Initiatives for Critical Agrarian Studies (BICAS), with funds from Ford Foundation Beijing, which has supported part of my fieldwork in Southern China. Some research funds are covered by the budget of Political Economy (PE) research group of ISS. I am sincerely grateful to their support.

Finally, I would like to express my deepest gratitude to my family. To my parents, thanks for their unconditional love. They always encouraged and supported me to overcome all kinds of difficulties and to pursue the path I chose. Lastly and most importantly, I want to thank Fengfeng, my beloved partner, soulmate, and best friend. He was the first one who encouraged me to pursue a PhD in the Netherlands. He believed in me and supported me both mentally and financially during this arduous journey. Without him, I would never have this work completed. 


\title{
Acronyms and abbreviations
}

\author{
ABD Accumulation by Dispossession \\ AWD Accumulation without Dispossession \\ HRS Household Responsibility System \\ ITP Industrial Tree Plantation \\ NGO Non-Governmental Organization \\ PA Primitive Accumulation \\ TNC Transnational Company
}



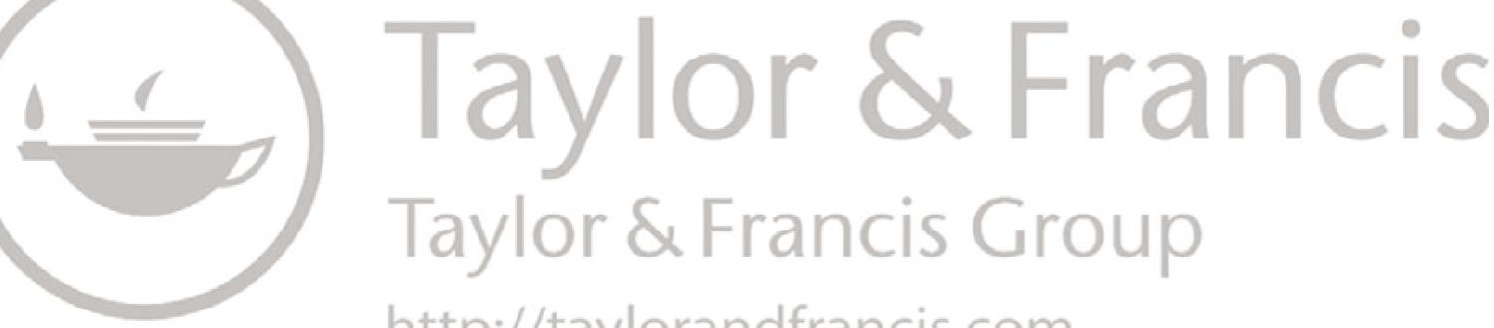

http://taylorandfrancis.com 


\section{Rethinking the industrial tree plantation sector in Southern China}

\section{Introduction}

In recent years, crop booms have occurred worldwide under the convergence of food, fuel, financial, and environmental crises (Hall 2011). As Hall (2011) points out, when a crop boom takes place, there is a rapid increase in the changes in land-use for the cultivation of that particular crop in a given area. This is not only a process of extensive land-use change, but is often followed by land acquisitions/ land grabs in varying ways and at various levels. These large-scale land acquisitions, popularly called 'land grabs', are highly visible worldwide in the current literature and political debates (Margulis, McKeon, and Borras Jr 2013). These land acquisitions include a dynamic change in land control: when someone gains access to land, those who were previously using it lose part of or full control of it. This aligns with the definition of land grabbing put forward by Borras Jr et al. (2012), that land grabbing is essentially a form of 'control grabbing': "grabbing the power to control land and other associated resources such as water in order to derive benefit from such control of resources" (Borras Jr et al. 2012, 850). These changes in land control and land-use have significantly affected the livelihoods of local villagers and, in some cases, even resulted in the dispossession of various social groups, normally the marginalized, and have provoked widespread conflicts (Scoones et al. 2013; White et al. 2012).

These crop booms have attracted a pyramid of academic studies, especially concerning land politics. In this book, land politics includes issues around who controls the land under what channel and for what land-use, who gets what from the land, and the implications of these land-based changes. ${ }^{1}$

Among the current crop booms, there is an expanding industrial tree plantation (ITP) sector in Southern China, currently large scale (in terms of total land area covered and capital involved). The rise of the sector there involves changes in both land-use and land control, at varying scales and dominated by foreign corporations (including Finnish and Indonesian ones) and a variety of domestic actors (including the state actors, domestic corporations, individual entrepreneurs, and local villagers). The commodities produced are mainly for industrial use. During this crop boom, the villagers in question are not fully expelled, because of the specific rural land system. ${ }^{2}$ Meanwhile, they have distinct livelihood changes and 


\section{Rethinking the ITP sector in China}

are affected differently due to their different positions in the sector (which include passive inclusion, active inclusion, passive exclusion, and active exclusion). ${ }^{3}$ In some places, the villagers embrace the land deals, while in others these land deals have provoked conflicts. These dynamics of the ITP sector in China are the focus of this book. By analysing these, this book intends to contribute to the current booming discussions on land politics - both empirically and theoretically.

Empirically, this work centres on one significant sector that has not received sufficient attention in the literature of land politics and highlights a more complicated role of China within the global land rush. To be specific, this study focuses on the rapidly expanding industrial tree plantation sector, which is linked to the increased demand for timber, pulp, and other biomass products (Kröger 2016). This has received much less attention compared to other sectors such as food, biofuels, and mining, despite its relative scale in terms of land area covered (Kröger 2014b). It deserves systematic research attention, if only because it is one of the biggest sectors in the current land rush in terms of land area involved. In addition, and perhaps even more importantly, this is also one sector that involves China in a more complicated way.

China is linked to the current global land rush as an investor in overseas production, a key player in the circulation/trade, and a key site of consumption, but rarely as an important destination of cross-border land investments within a crop boom. Where studies about land grabbing in China exist, the research is mainly about forced/illegal land transfers (tudi liuzhuan), ${ }^{4}$ or development-induced land expropriation (Siciliano 2013, 2014). ${ }^{5}$ So, this case can single out China as a distinct area of research in the global land politics literature.

Theoretically, analysing the dynamics of the ITP sector in China also offers insights to a better understanding of land grabbing (including its nature, mechanisms, and impacts) and contributes to the discussions around land accumulation and dispossession. More specifically, there is a general assumption in the current land grabbing literature that the current corporate encroachment into rural areas tends to result in the expulsion of people from their land, and their transformation into landless labourers that mostly support the industrial development of urban areas.

However, this case deviates from this popular assumption. With the rise of the ITP sector in Southern China, villagers do not necessarily get dispossessed and become more vulnerable. Instead, villagers show diverse adaptive livelihood responses based on their different access to resources under specific institutional and social structures. As a result, villagers do not always lose, but at times can benefit, from the boom process. In addition, this Chinese ITP case also shows a reverse labour and capital inflow from urban areas to rural areas, with a few villagers returning to rural areas and engaging in the ITP sector with the financial capital they gained in urban industrial sectors.

Therefore, the dynamics within the expansion of the ITP sector in Southern China demonstrate that capital accumulation is possible not only with but also without dispossession of villagers. Thus, an in-depth exploration of this case can open an agenda for discussions in the global scholarship on contemporary land politics and agrarian transformations. 


\section{Accumulation and dispossession in agrarian transformations - glances at the ITP sector in Southern China}

Many scholars use Marx's "primitive accumulation” and David Harvey's "accumulation by dispossession" to understand land dynamics in terms of its drivers (for accumulation), mechanisms (dispossession, and mainly coercion), and implications (reproduction of capitalist relationships) (Hall 2013). In this book, instead of an attempt to unfold these loaded theories, I intend to position land politics, especially the dynamics of the land-labour nexus and livelihood change of the villagers, with the rise of the ITP sector in Southern China (in particular Guangxi), based on the classic discussions around "accumulation and dispossession". In this part, I particularly focus on the "land-labour nexus", which refers to the interconnected and interacted land and labour dynamics within the boom.

\section{Accumulation with and without dispossession}

Karl Marx was the first to give a critical analysis of the process of separating peasants from their means of production during capitalist development. In Capital: Vol. 1, A Critique of Political Economy (Marx 1992, orig. 1887), Marx analysed the sources, characteristics, and mechanisms of capital by studying the history of western countries - especially the birthplace of capitalism, namely, England. When analysing the point of departure of the capitalist mode of production, he touched on the relationship between capitalism and rural development, and coined the concept of primitive accumulation (PA) - "the historic process of divorcing the producer from the means of production" (Marx 1992, orig. 1887, 875). In so doing, he used the capitalist development process of European countries (such as England) to demonstrate how the expropriation of peasants through the forceful expulsion from their land supplied the capitalist labour market with "free and rightless proletarians" (Marx 1992, orig. 1887, 885).

According to Marx, the primitive accumulation involved bloody processes of proletarianization. During the process, peasants were expropriated and expelled from land via fraud, force, violence, and coercion. This, on the one hand, enabled capitalists to have their wealth and power significantly increased through the control over the means of production; while, on the other hand, it created a reserve army of labour serving as cheap wage labour in urban industrial sectors. (Marx 1992, orig. 1887, 908-913). In both ways, separating peasants from land facilitated the process of urban industry.

Marx conceptualized primitive accumulation as a stage towards capitalism, or a precondition for capitalist accumulation, which he assumed would end when capitalism emerged. Based on Marx, David Harvey argues that primitive accumulation is not a stage in a unilinear process towards capitalism, but an ongoing feature of capitalism. Extending Marx's concept, Harvey proposes "accumulation by dispossession" (ABD) (Harvey 2003, 1) to understand the reproduction of capitalist relationships and continuous accumulation under the crisis of over-accumulation. 


\section{Rethinking the ITP sector in China}

In his explanation of $\mathrm{ABD}$, Harvey argues that although a large part of features of PA that Marx outlined have remained, there are several nuances that exist in the current context (Harvey 2003, 145). One the one hand, "some of the mechanisms of primitive accumulation that Marx emphasized have been fine-tuned to play an even stronger role now than [in] the past" (Harvey 2003, 146-147). This was the case for the role of the "credit system and financial capital" in fuelling the process of speculation and predation in contemporary capitalism, and that of the state in guaranteeing "certain structures of law, private property, contract and security of money" to facilitate the market system during accumulation through its "police powers and a monopoly over the means of violence" (Harvey 2003, 89). On the other hand, there are some new mechanisms. The development of technology, the degradation of the environment, and the depletion of common resources have created new fields of accumulation - entailing the privatization and commodification of "cultural forms, histories, and intellectual creativity" (Harvey 2003, 148). Meanwhile, capital assets and labour power are devalued in response to global crises by international capital - sometimes backed by the investor state or superior state powers (Harvey 2003, 151).

Expanding the discussion above, and doing so within the context of China, Walker (2006) argues that the "alliance between money and power (...) has generated a particular form of primitive accumulation", which she terms "gangster capitalism" (Walker 2006, 1). She identified three main mechanisms of "gangster capitalism" in rural China. First, the state's "urban bias" strategy in the 1990s, which prioritized urban development while reducing agricultural investment, was actually a case of state-organized "exploitation and oppression of peasants" (Walker 2006, 2). Second, the "two tract pricing system" (between agricultural products and industrial commodities) enabled the state-owned enterprises to obtain cheap raw materials and extract resources in rural areas (Walker 2006, 3). ${ }^{6}$ Third, a few power-holders used the rural land reform (i.e. Household Responsibility Reform) of the 1980s-1990s as opportunities to illegally shift "state property and assets into their own hands" (Walker 2006, 3-5). These three mechanisms, according to Walker, facilitated the industrial development and the accumulation of a few certain actors at the expenses of rural development and thus are closely associated with how land, labour, and agrarian transformation can proceed.

Although the mechanisms and distinct socio-economic contexts of capital accumulation identified by these scholars differ across time and space, the processes all lead to dispossession and, in most cases, displacement of rural populations. In this sense, capital accumulation is featured cum dispossession, under which villagers lose control over the land they previously used and hardly get employed by the land investors.

Contrarily, Giovanni Arrighi argues that accumulation can occur without necessarily dispossessing villagers. When studying the success of Chinese economic development, he expands the notion of accumulation without dispossession (AWD) (Arrighi 2007). AWD, a term coined by Gillian Hart (2002) in her book Disabling globalization: Places of power in post-apartheid South Africa, is a distinctive 
form of accumulation in China, which differs from the accumulation process in South Africa. Hart argues that the redistributive land reform in China reflects the specific context of Chinese industrial accumulation that took place without dispossessing rural populations from their land (Hart 2002, 199). ${ }^{7}$

Building on Hart's reformulation of PA and ABD, Arrighi further explained the mechanism of AWD by addressing two aspects. On the one hand, China's household registration system (the Hukou regime) ${ }^{8}$ prevented the spatial mobility of the rural population and "encouraged the rural to "leave the land without leaving the village” [离土不离乡] (Arrighi 2007, 361). The Hukou regime separates rural populations from the urban ones and is the basis for rural land distribution. ${ }^{9}$ Thus, it in fact ties the villagers to the land, averting the full expulsion of these villagers from their land. On the other hand, the rise of Township and Village Enterprises (TVEs, the market-oriented but collectively owned economic units) in rural China from the 1980s to the early 1990s also supported AWD. TVEs provided off-farm working opportunities for villagers to obtain additional wages, while maintaining subsistence farming as a way to redistribute and reinvest the industrial surplus to the rural community "within local circuits" (Arrighi 2007, 361-364). ${ }^{10}$ This means that companies could accumulate capital, not necessarily by separating the producers from their means of production (as in PA and ABD), but by employing low-cost rural labourers.

Partly in in line with Arrighi's arguments, Huang, Gao, and Peng (2012) also claimed that the process of rural capitalism is not necessarily accompanied by "the spread of an agricultural proletariat" (139). Based on an empirical analysis of hired labour in the agricultural sector, they characterized agricultural development in China as "capitalization without proletarianization". They attributed this special form of capitalization to "the concatenation of the political-economic institutions (of equal distribution of land and a rural-urban divide in household registration) of China with its mode of farm organization under population pressure" (Huang, Gao, and Peng 2012, 165). In other words, one the one hand, villagers' landholdings compensate their low wages in urban areas, thus sustaining a substantial supply of cheap labour for urban industry. On the other hand, wages from off-farm work also alleviate villagers' livelihood pressures due to a low return of farming on fragmented and tiny land plots (under the particular land system which will be elaborated below).

Similarly, Chuang (2015), in her study of a village in the Sichuan Province, pointed out that although land expropriations - following the scheme of ABD also exist in rural China, "[l]abor, however, is cheapest in rural regions where residents are not dispossessed, and continue to subsist through farming" (292). She identified and examined one of the key mechanisms of AWD in contemporary China as enterprises employing rural land holders on very low wages to pass on the "social cost of workforce maintenance to rural governments" (275).

Thus, in contrast to PA/ABD, in the process of AWD, capitalists are able to accumulate without dispossession. In this context, investors are able to use cheap labour and create a reserve labour army without separating villagers from their means of production. 


\section{Rethinking the ITP sector in China}

\section{Diverse trajectories in the rise of the ITP sector in Guangxi}

A key issue in the discussion on PA, ABD, and AWD is what happens to the villagers in question. Linking these concepts to a crop boom, in the classic Marxist conception of PA, dispossessing villagers of land is a key element of the accumulation process. Similarly, Harvey also pointed out a renewed wave of land enclosure in new terrains (e.g. in China after its opening up) during ABD. Thus, as summarized in Figure 1.1, when capital accumulation emerges with dispossession (Type A), the villagers are dispossessed of land and not recruited by investors. As a consequence, these villagers are bound to become more vulnerable due to the loss of land (as a key livelihood source) and then usually get excluded within a crop boom.

In Arrighi's AWD, however, as mentioned above, villagers are not necessarily dispossessed of land during capital accumulation, especially in the case of China, because of the role of certain institutions - namely, the household registration system (Hukou), the land property regime, and natural endowment (in terms of high or low land density, which will be elaborated on later in this chapter) - in preventing the complete expulsion process and protecting family farms. ${ }^{11}$ In this sense, there is a possible alternative direction of change in the process of capital accumulation (Type B): the villagers do not lose land while being employed by land investors. Thus, they are able to get included in a crop boom and at times be better-off, because, rather than lose their previous source of livelihood, the villagers might have their livelihoods expanded through employment in the booming sector.

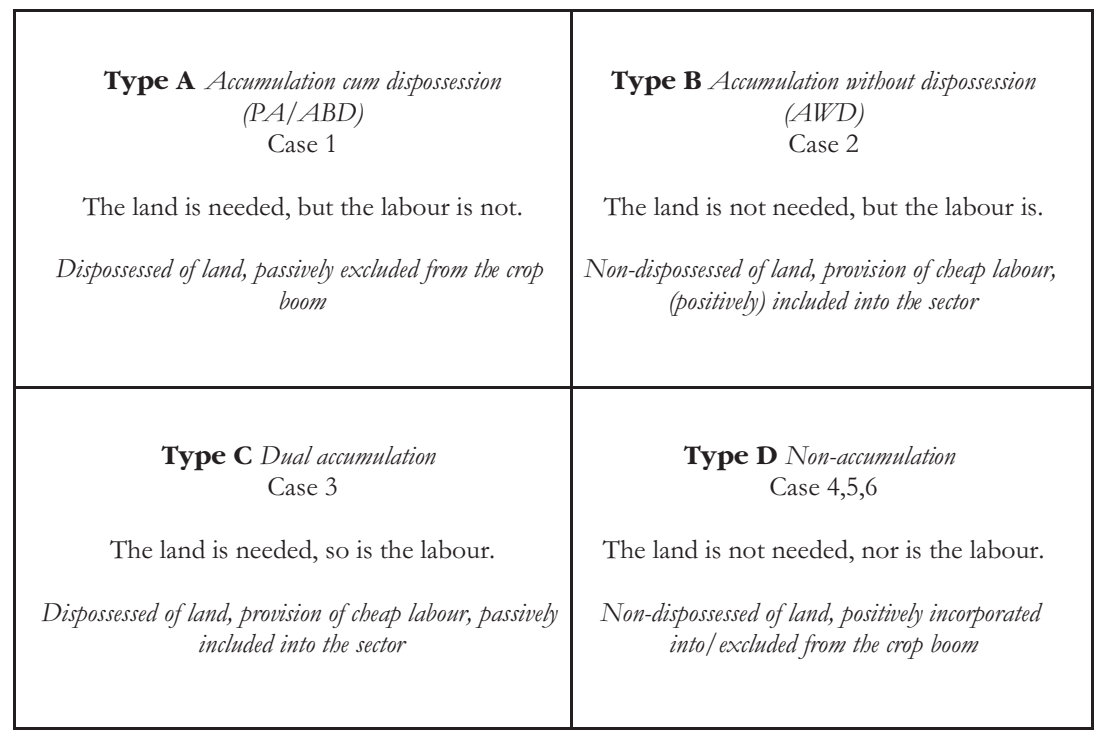

Figure 1.1 Accumulation schemes within the rise of the ITP sector in Southern China. Source: author's elaboration. 


\section{Notes}

1 In other words, land politics includes a bundle of policies/actions from above and a series of initiatives/reactions from below that are associated with land entitlement and the direction of changes in land control and land-use. These actions from above and from below are neither independent nor do they emerge in sequence, but dynamically (re)shape each other. They are around land-based change, but not always land-centric (e.g. about labour and ecology).

2 Under the current land system in China, rural land is owned by the collectives, while the contracting rights are entitled to villagers based on their rural identity (under the Hukou System), and the management rights belong to the actual users of the land. Thus, what can be transferred to investors is the user right of the land rather than full ownership. This will be elaborated on in Chapters 1 and 2 .

3 In this study, the term 'villagers' is used on purpose to refer to socially differentiated rural residents. Villagers are not the same as the "peasants" who, as defined by Chayanov, only conduct subsistence farming. Many villagers do off-farm work. Meanwhile, they are not backward and low quality as discussed in contemporary narratives about Chinese peasants (see Schneider 2015). They have their specific advantages. Furthermore, some villagers are not purely 'smallholders'. Although villagers in China usually have small, even tiny, plots, some have acquired more land as an adaptive livelihood strategy. This will be analysed in the following sessions/chapters.

4 In China, due to the specific land system which will be introduced in the following parts, rural land cannot be sold, but (the user rights) can be contracted. Thus, in the context of China, land transfer is what has been commonly discussed by Chinese scholars (Z. Huang and Wang 2008).

5 These domestic land grabs have occurred not only in rural areas but also in urban areas, as commonly shown in current media and activism, such as: www.amnesty.org/ en/latest/news/2011/12/china-must-end-land-grabs-amid-protests-over-death-custody/, accessed on 16 January 2018.

6 The two-track pricing system is the transitional pricing system implemented when China moved from a centrally planned economic system to a market-dominated economic system. Under such a system, part of the raw materials is sold to the state at the planned price, while the rest can be sold at market prices (http://baike.baidu.com/ view/538126.htm, accessed on 11 January 2017). This means that government officials and managers in SOEs can buy at a cheap (state) price, stockpile, and then sell at a high (market) price to make huge profits. This process underlies the creation of the first 'cadre-capitalist class', see Hung (2015).

7 Also cited in Arrighi, Aschoff, and Scully (2010, 416).

8 A formal registration of the population by government, based on the household unit, and with a strict division between the rural and urban populations. The system was introduced in the early 1950s as a statistical/ recording system and, from the late 1950s, became an institution to control geographical mobilization (Chan and Zhang 1999). Under this system, citizens are classified by socio-economic eligibility ("agricultural" and "non-agricultural") and residential location ("local" and "non-local"). The classification is related to citizens' entitlements to the resources and services provided by the state. Thus, without a local non-agricultural Hukou, it would be difficult for a citizen to permanently live in the city. The Hukou system, though it has gone through a variety of reforms, still "directly and indirectly, continues to be a major wall in preventing China's rural population from settling in the city and in maintaining the rural-urban 'apartheid"' (Chan and Buckingham 2008, 604).

9 Rural land rights in China are closely linked to Hukou status. Under the Household Reform System (HRS) reform, the land-user rights were allocated to rural dwellers with an agricultural Hukou in the village community they belong to. These rural dwellers would not lose their land rights unless they give up their local agricultural Hukou (Andreas and Zhan 2016). However, Andreas and Zhan (2016) have noticed a gradual shift in land rights from being Hukou-based to being more market-based under the current Hukou and land reforms.

10 Note that, after a short-lived period of prosperity in the 1990s, these TVEs have already declined (Buck 2007). 
11 A few scholars have different opinions about the same institutions (e.g. TVEs). According to Arrighi (2007, 362-363), collectively owned TVEs emerged in rural China during the period of fiscal decentralization to promote local economic development and increase cadres' bonuses. The role of TVEs in redistributing surplus is expressed in two ways, namely: paying taxes and levies to rural communities, and employing rural surplus labour to raise villagers' incomes. However, Walker (2006) argues that TVEs are used as tools for extracting rural surplus. In other words, where Walker argues that TVEs, rather than being organizations that redistribute the surplus from urban to rural areas within the AWD scheme, simply fuel a new round of extraction in rural areas, Arrighi claims that TVEs enable capital to reflow from urban to rural areas with capitalist development. Both Arrighi's and Walker's explanations are supported by empirical evidence from contemporary rural China, but in different regions and during different time periods: Webber (2008) argues that the TVEs, under the protection of local states within the context of a non-competitive, centrally planned economic regime, did indeed improve villagers' welfare by subcontracting work from the urban industrial sector. Buck (2007), meanwhile, states that TVEs reformed the rural land-labour relationship, and changed the rural farmers into subordinated wage workers. According to R. Walker and Buck (2007, 43-44), when TVEs privatized or closed in the context of the market economic regime in the late 1990s, these rural workers were forced to become the industrial reserve army. This is a reminder to pay attention to differences across space and time when studying the rise of capitalism and its rural-urban linkage.

12 Findings from my fieldwork in 2016 show that 13 of the interviewed villagers were doing unskilled wage-labour jobs in the ITP sector (i.e. weeding and fertilizing). Their average annual income from these jobs was 3,342 yuan per capita, which is very little compared to the average annual wage income in China (67,569 yuan per capital in 2016). Data from the National Bureau of Statistics of China: http://data.stats.gov.cn/ easyquery.htm?cn=C01.

13 In China, forestland is a type of land classified by the state. It is hilly land but not necessarily with natural forests on it.

$14 \mathrm{Mu}$ refers to a unit for the measurement of land - 15 mu equals 1 hectare.

15 Although, according to Q. F. Zhang (2012), Chinese contract farming might contain some distinct features.

16 His study is based on contemporary land grabs in the context of an Indonesian palm oil plantation. The notion of adverse incorporation, "as a fairly broad critique of neoliberal accounts of poverty and development", refers to "the risks and disadvantages of inclusion and participation in unregulated capitalist markets" (du Toit 2009, 2).

17 Yuan is the monetary unit of China. One euro equals 7.1 Yuan.

18 Beihai, Nanning, Qianzhou, Qinlian, Yunlin, and Wuzhou are all cities in Guangxi.

19 This might be different from maize production in the Northeast of China, which tends to encompass large-scale and highly industrialized production (Gale, Jewison, and Hansen 2014).

20 In this book, I mainly focus on the politics of land-use change rather than broader geographic and ecological measurements in land-use changes (including land cover, biomass, etc.).

211 hectare equals $15 \mathrm{mu}$.

22 See www.china.org.cn/china/CPC_90_anniversary/2011-04/19/content_22392494.htm, accessed on 11 September 2018.

23 The data comes from the Statistic Year Book of China 2013: www.stats.gov.cn/tjsj/ ndsj/2013/indexch.htm, accessed on 11 January 2017.

24 http://baike.baidu.com/view/6054077.htm, accessed on 11 January 2017.

25 www.gov.cn/zhengce/2018-09/26/content_5325534.htm, accessed on 29 October 2019.

26 Data source: www.stats.gov.cn/tjsj/zxfb/201704/t20170428_1489334.html, accessed on 16 April 2018. 
27 I said "villagers leave land", because villagers are doing off-farm work and have physically left the land and farming activities. But this does not mean that villagers have been legally separated from land, either voluntarily or forced.

28 http://cpc.people.com.cn/GB/134999/135000/8104098.html, accessed on 11 January 2017.

29 There are different types of subsidies for different type of forests/plantations. Under the Returning Farmland to Forest Program, planters got 210 yuan per mu per year for five years (as commercial forests/plantations) or eight years (as ecological forests/ plantations). In 2007, the central state prolonged the subsidies for another five or eight years at reduced rates of 125 yuan (Zinda et al. 2017). The subsidies and free seedlings increased the economic incentives for villagers in Guangxi to plant eucalyptus trees.

30 http://news.xinhuanet.com/theory/2008-12/18/content_10522035.htm, accessed on 11 January 2017.

31 Except for the regular agriculture tax, peasants still had to pay fees and charges called "five tongshou three tiliu". These were: family planning, social special care, militia training, road construction, and education fees at the township level (five tongshou), and public accumulation funds, public welfare funds, and administration fees at the village level (three tiliu). There were also other charges, such as "self-raised funds" (jizi), and apportions (tanpian).

32 “辛辛苦苦三百天, 酒尽汗水责任田; 亩产千斤收成好, 年终结算亏本钱” (http://news. ifeng.com/special/60nianjiaguo/60biaozhirenwu/renwuziliao/200909/0910_7766_1342 837.shtml, accessed on 11 January 2017). A new year couplet is a decoration pasted on the door and always expresses wishes for the new year.

33 “农民真苦, 农村真穷, 农业真危险” (http://blog.sciencenet.cn/blog-518437-522104.html, accessed on 11 January 2017).

34 http://zh.wikipedia.org/wiki/\%E5\%86\%9C\%E6\%9D\%91\%E7\%A8\%8E\%E8\%B4\%B9\% E6\%94\%B9\%E9\%9D\%A9, accessed on 11 January 2017.

35 www.gov.cn/test/2006-03/06/content_219801.htm, accessed on 11 January 2017.

36 However, similarly to soy and maize in Northeast China (Hairong, Yiyuan, and Hok Bun 2016, 381), the profitability of a crop is not simply affected by economic factors. As will be analysed in Chapter 3, it is also related to the state's strategic control of the prices of certain crops (including sugarcane), but not other crops (e.g. eucalyptus trees).

37 During my preliminary fieldwork in 2014, employees of the Guangxi Forestry department told me of the plan to limit the scale of ITPs in Guangxi. Some counties in Guangxi and Guangdong have issued policies to stop the planting of eucalyptus trees and plan to completely remove the ITPs already planted, due to their negative environmental impacts and the resistance from below that they generate: http://news.sohu. com/20060411/n242749631.shtml, www.eeo.com.cn/2014/0815/264952.shtml,_accessed on 11 January 2017.

38 The state-owned forest farms (e.g. Dongmen State-owned Forest Farm, Gaogeng Stateowned Forest Farm) are also "Dragon Head Enterprises". For a more detailed analysis of "Dragon Head Enterprises" and its role in the rural capitalization in China, see Schneider (2017).

39 This information comes from the interview with employees at Store Enso and from a state farm during my preliminary fieldwork in spring 2014.

40 I refer to the total scale of land leased by state forest farms rather than the scale of each case.

41 Although this is a special case, because the enclosure was done in order to create a non-agricultural, special economic zone - similar to what Levien studied in India (Levien 2012).

42 This is different from the findings by Deng and Yang $(2013,321)$, in that, in the face of real and serious pollution, villagers may seek to redress environmental grievances by piggybacking on politically favourable issues.

43 Of these interviews, 105 were conducted with questionnaires as guidelines.

44 Because my fieldwork is conducted in multiple sites. Although snowball sampling might show bias due to the selection of the first few participants, this is a method 
that could help me quickly access key informants, especially those who were involved in the conflicts. During the process, I selected and visited varying sites with distinct dynamics of the crop boom and in each site tried to start by interviewing normal vil lagers rather than local elites (e.g. rich farmers and village leaders).

45 In this book, except a few cases (when the information came from newspapers and/or was already well known), most village names are pseudonyms (replaced by letters of the alphabet) to protect the informants.

46 http://baike.baidu.com/subview/327591/7967028.htm, accessed on 11 January 2017.

47 This number needs further examination as he is employed by Stora Enso to guard the plantation.

48 According to the data provided by officials in the county.

49 Some of the interviews did not follow the pattern in the questionnaires. Furthermore, a few interviews were interrupted for various reasons. These interviews are considered "incomplete" in this Table.

50 In some natural villages I visited, the farmland had already been leased out to entre preneurs/companies for large-scale sugarcane cultivation.

\section{References}

Andreas, Joel, and Shaohua Zhan. 2016. "Hukou and Land: Market Reform and Rural Displacement in China." Journal of Peasant Studies 43 (4): 798-827. https://doi.org/10. 1080/03066150.2015.1078317.

Arrighi, Giovanni. 2007. Adam Smith in Beijing: Lineages of the Twenty-First Century. London and New York: Verso.

Arrighi, Giovanni, Nicole Aschoff, and Ben Scully. 2010. "Accumulation by Dispossession and Its Limits: The Southern Africa Paradigm Revisited." Studies in ComparativeInternationalDevelopment45 (4):410-438.https://doi.org/10.1007/s12116-010. 9075-7.

Bernard, Harvey Russell. 2000. Social Research Methods: Qualitative and Quantitative Approaches/H. Russell Bernard. Thousand Oaks, CA [etc.]: Sage Publications. http://eur. summon.serialssolutions.com/2.0.0/link/0/eLvHCXMwY2AwNtIzOEUrE8zS0tKASS XFOiDRJNXcOizZ2NwyydwgzTAFiMzBd08gDuTjQZRbbkIMTK15ogzybq4hzh66qa XAyAI1wMADHPHAusbCAlhlGRuKMfAmglaE55WAd461SDAoWKalpZiZG VgCa3xLk9SU1MRUy1TTRBMjw1RLc6DDLQHZqyvT.

Bernstein, Henry. 2010a. Class Dynamics of Agrarian Change. Halifax: Fernwood Publishing.

. 2010b. "Introduction: Some Questions Concerning the Productive Forces." Journal of Agrarian Change 10 (3): 300-314.

Bernstein, Thomas P., and Xiaobo Lü. 2003. Taxation without Representation in Contemporary Rural China. Cambridge: Cambridge University Press.

Blaikie, Piers. 1995. "Changing Environments or Changing Views? A Political Ecology for Developing Countries." Geography 80(3), 203-214.

Blaikie, Piers, and Harold Brookfield. 1987. Land Degradation and Society. London: Methuen.

Borras Jr, Saturnino M., and Jennifer C. Franco. 2012. "Global Land Grabbing and Trajectories of Agrarian Change: A Preliminary Analysis." Journal of Agrarian Change 12 (1): 34-59. https://doi.org/10.1111/j.1471-0366.2011.00339.x. 
Borras Jr, Saturnino M., Jennifer C. Franco, S. Gomez, Cristóbal Kay, and Max Spoor. 2012. "Land Grabbing in Latin America and the Caribbean." Journal of Peasant Studies 39 (3-4): 845-872. https://doi.org/10.1080/03066150.2012.679931.

Bräutigam, Deborah, and Haisen zhang. 2013. "Green Dreams: Myth and Reality in China's Agricultural Investment in Africa." Third World Quarterly 34 (9): 1676-1696. https://doi.org/10.1080/01436597.2013.843846.

Buck, Daniel. 2007. "The Subsumption of Space and the Spatiality of Subsumption: Primitive Accumulation and the Transition to Capitalism in Shanghai, China." Antipode 39 (4): 757-774.

Buckley, Lila. 2013. "Chinese Land-Based Interventions in Senegal." Development and Change 44 (2): 429-450. https://doi.org/10.1111/Dech.12016.

Calder, Ian R. 2003. "Eucalyptus, Water and the Environment." In Eucalyptus: The Genus Eucalyptus, edited by John J.W. Coppen, 1st ed., 36. London: Taylor and Francis.

Calder, Ian R., Paul T.W. Rosier, K.T. Prasanna, and S. Parameswarappa. 1997. "Eucalyptus Water Use Greater than Rainfall Input-Possible Explanation from Southern India." Hydrology and Earth System Sciences Discussions 1 (2): 249-256.

Carriere, Ricardo, and Larry Lohmann. 1996. Pulping the South: Industrial Tree Plantations and the World Paper Economy. London: Zed books.

Chan, Kam Wing. 2010. "The Household Registration System and Migrant Labor in China: Notes on a Debate." Population and Development Review 36 (2): 357-364. https:// doi.org/10.1111/j.1728-4457.2010.00333.x.

Chan, Kam Wing, and Will Buckingham. 2008. "Is China Abolishing the Hukuo System?" China Quarterly 195 (195): 582-606. https://doi.org/10.1017/S030574100 8000787.

Chan, Kam Wing, and Li Zhang. 1999. "The Hukou System and Rural-Urban Migration in China: Processes and Changes.” The China Quarterly 160: 818-855. https://oi.org/ 10.3366/ajicl.2011.0005.

Chen, Yiyuan. 2013. "Zibenzhuyi Shi Jiating Nongchang de Xingqi Yu Nongye Jingying Zhuti Fenhua de Zai Sikao [The Rise of Capitalist Family Farms and a Reflection on the Differentiation of Agricultural Subjects]." Kaifang Shidai [Open Times] 4: $137-156$.

Chuang, Julia. 2015. "Urbanization through Dispossession: Survival and Stratification in China's New Townships.” Journal of Peasant Studies 42 (2):275-294. https://doi.org/10.1080/ 03066150.2014.990446.

Das, Raju J. 2007. "Introduction: Peasant, State and Class." The Journal of Peasant Studies 34 (3-4): 351-370.

Day, Alexander F. 2013. The Peasant in Postsocialist China: History, Politics, and Capitalism. Cambridge: Cambridge University Press.

Deng, Yanhua, and Guobin Yang. 2013. "Pollution and Protest in China: Environmental Mobilization in Context." China Quarterly 214 (214): 321-336. https://doi.org/10.1017/ S0305741013000659.

Ding, Lin. 2017. "China Outlines Roadmap for Rural Vitalization - Xinhua | English.News. Cn.” Xinhua. 2017. http://www.xinhuanet.com/english/2017-12/30/c_136860538.htm.

Edelman, Marc. 2013. "Messy Hectares: Questions about the Epistemology of Land Grabbing Data." Journal of Peasant Studies 40 (3): 485-501. https://doi.org/10.1080/03066150. 2013.801340. 
FAO. 2010. “Global Forest Resources Assessment.” FAO Forestry Paper. http://www.fao.org/ docrep/013/i1757e/i1757e.pdf:

Fox, Jonathan. 1993. The Politics of Food in Mexico: State Power and Social Mobilization. Ithaca: Cornell University Press.

Friedmann, Harriet. 2016. "Commentary: Food Regime Analysis and Agrarian Questions: Widening the Conversation." The Journal of Peasant Studies 43 (3): 671-692. https://doi. org/10.1080/03066150.2016.1146254.

Gale, Fred, Michael Jewison, and Jim Hansen. 2014. Prospects for China's Corn Yield Growth and Imports. Washington, DC: Department of Agriculture Economic Research Service. Available at: https://www.ers.usda.gov/publications/pub-details/?pubid=36737.

Gerber, Julien-FranÇOis. 2011. "Conflicts over Industrial Tree Plantations in the South: Who, How and Why?" Global Environmental Change-Human and Policy Dimensions 21 (1): 165-176. https://doi.org/10.1016/j.gloenvcha.2010.09.005.

Gerber, Julien-FranÇOis, and Sandra Veuthey. 2010. "Plantations, Resistance and the Greening of the Agrarian Question in Coastal Ecuador." Journal of Agrarian Change 10 (4): 455-481. https://doi.org/10.1111/j.1471-0366.2010.00265.x.

Gramsci, Antonio. 1999. Prison Notebooks: Further Selections from the Prison Notebooks, London: Electric Book Company Ltd.

Gray, Dennis. 2008. "China Farms the World To Feed a Ravenous Economy.” 2008. http:// www.akha.org/content/environment/dennisgraylaos.html.

Hall, Derek. 2011. "Land Grabs, Land Control, and Southeast Asian Crop Booms." Journal of Peasant Studies 38 (4): 837-857. https://doi.org/10.1080/03066150.2011.607706.

2013. "Primitive Accumulation, Accumulation by Dispossession and the Global Land Grab." Third World Quarterly 34 (9): 1582-1604. https://doi.org/10.1080/01436597. 2013.843854.

Hart, Gillian Patricia. 2002. Disabling Globalization: Places of Power in Post-Apartheid South Africa. Vol. 10. Berkeley: University of California Press.

Harvey, David W. 2003. The New Imperialism: David Harvey. Oxford: Oxford University Press.

He, Guizhen, Lei Zhang, Arthur P J Mol, Yonglong Lu, and Jianguo Liu. 2013. "Revising China's Environmental Law." Science 341 (6142): 133.

He, Xuefeng. 2011. "Quxiao Nongyeshui Hou Noncun de Jiecun Fenxi ( the class analysis in rural areas after the elimiation of agricultural tax)." Wenshibolan 4: 41-47.

Hesse-Biber, Sharlene Nagy. 2010. Mixed Methods Research: Merging Theory with Practice. New York: The Guilford Press.

Ho, Peter, and Max Spoor. 2006. "Whose Land? The Political Economy of Land Titling in Transitional Economies." Land Use Policy 23 (4): 580-587. http://ac.elscdn.com/S0264837705000402/1-s2.0-S0264837705000402-main.pdf?_tid=502ccb 48-bf91-11e5-974c-00000aab0f26\&acdnat $=1453306834 \_64 f 756458 \mathrm{c} 85 \mathrm{f} 03 \mathrm{~b} 5 \mathrm{~d} 90 \mathrm{~d}$ $4642 \mathrm{a} 24 \mathrm{c} 8 \mathrm{~b} 7$.

Huang, Philip C.C. 2011. "China's New-Age Small Farms and Their Vertical Integration: Agribusiness or Co-Ops?" Modern China 37 (2): 107-134. https://doi.org/10. 1177/0097700410396476.

Huang, Philip C.C., Yuan Gao, and Yusheng Peng. 2012. "Capitalization without Proletarianization in China's Agricultural Development." Modern China 38 (2): 139-1373. https://doi.org/10.1177/0097700411435620.

Huang, Zuhui, and Peng Wang. 2008. "Rural Land Transfer: Current Situations, Problem and Responses (农村土地流转: 现状，问题及对策).” The Journal of Zhejiang University (Humanities and Social Science) 38 (2): 38-47. http://www.cnki.com.cn/ 
Article/CJFDTOTAL-ZJDX200802011.htm.

Hung, Ho-fung. 2015. The China Boom: Why China Will Not Rule the World By. New York: Columbia University Press. https://doi.org/10.1353/gss.2016.0036.

Jessop, Bob. 2011. "Poulantzas's State, Power, Socialism as a Modern Classic." In Reading Poulantzas, edited by Bretthauer L. et al. London: Merlin.

Kennedy, John James. 2007. "From the Tax-for-Fee Reform to the Abolition of Agricultural Taxes: The Impact on Township Governments in North-West China." China Quarterly 189: 43-59. https://doi.org/10.1017/S0305741006000798.

_. 2013. "Finance and Rural Governance: Centralization and Local Challenges." Journal of Peasant Studies 40 (6): 1009-1026. https://doi.org/10.1080/03066150.2013. 866096.

Kröger, Markus. 2012. "The Expansion of Industrial Tree Plantations and Dispossession in Brazil." Development and Change 43 (4): 947-973. https://doi.org/10.1111/ j.1467-7660.2012.01787.x.

2014a. Flex Trees: Political and Rural Dimensions in New Uses of Tree-Based Commodities. Think Piece Series on Flex Crops \& Commodities No. 2, 1-14. Amsterdam: Transnational Institute (TNI).

- 2014. "The Political Economy of Global Tree Plantation Expansion: A Review." Journal of Peasant Studies 41 (2): 235-261. https://doi.org/10.1080/03066150. 2014.890596.

. 2016. "The Political Economy of 'Flex Trees': A Preliminary Analysis." Journal of Peasant Studies 43 (4): 886-909. https://doi.org/10.1080/03066150.2016.1140646.

Kung, J.K.S. 2000. "Common Property Rights and Land Reallocations in Rural China: Evidence from a Village Survey." World Development 28 (4): 701-719. https://doi.org/ $10.1016 / S 0305-750 x(99) 00148-5$.

Lenin, Vladimir Il'ich. 1978. State and Revolution: Marxist Teaching about the Theory of the State and the Tasks of the Proletariat in the Revolution. Moscow: Progress Publishers.

Levien, Michael. 2012. "The Land Question: Special Economic Zones and the Political Economy of Dispossession in India." Journal of Peasant Studies 39 (3-4): 933-969. https:// doi.org/10.1080/03066150.2012.656268.

Li, Linda Chelan. 2007. "Working for the Peasants? Strategic Interactions and Unintended Consequences in the Chinese Rural Tax Reform." The China Journal 57, 89-106.

Li, Ping, and Robin Nielsen. 2010. A Case Study on Large-Scale Forestland Acquisition in China: The Stora Enso Plantation Project in Hepu County, Guangxi Province. Washington, DC: Rights and Resources Initiative.

Li, Tania Murray. 2011. "Centering Labor in the Land Grab Debate." Journal of Peasant Studies 38 (2): 281-298. https://doi.org/10.1080/03066150.2011.559009.

Li, Xiande. 2003. "Rethinking the Peasant Burden: Evidence from a Chinese Village." Journal of Peasant Studies 30 (3-4): 45-+.

Liu, Jianguo. 2010. "China's Road to Sustainability." Science 328 (5974): 50. http://science. sciencemag.org/content/sci/328/5974/50.full.pdf.

Liu, Yang. 2010. "APP Guangxi Plantation-Pulp-Paper Integration Project (APP广西 金桂林浆纸一体化项目).” 2010. http://finance.people.com.cn/GB/67723/67730/126 80269.html.

Lu, Xiaobo. 1997. "The Politics of Peasant Burden in Reform China." Journal of Peasant Studies 25 (1): 113-138. https://doi.org/10.1080/03066159708438660.

Lungo, A. Del, J. Ball, and J. Carle. 2006. "Global Planted Forests Thematic Study. Re- 
sults and Analysis." Planted Forests and Trees Working Papers (FAO). http://agris.fao.org/ openagris/search.do?recordID=XF2007431885.

Margulis, Matias E., Nora McKeon, and Saturnino M. Borras Jr. 2013. "Land Grabbing and Global Governance: Critical Perspectives." Globalizations 10 (1): 1-23. https://doi. org/10.1080/14747731.2013.764151.

Marx, Karl. 1992, orig. 1887. Capital: Vol. 1, A Critique of Political Economy, Trans. Ben Fowkes. New York: Penguin.

Marx, Karl, and Friedrich Engels. 1969. Manifesto of the Communist Party. Marx/Engels Selected Works, Vol. One. Moscow: Progress Publishers, pp. 98-137.

McCarthy, John F. 2010. "Processes of Inclusion and Adverse Incorporation: Oil Palm and Agrarian Change in Sumatra, Indonesia." The Journal of Peasant Studies 37 (4): 821-850.

Mol, Arthur P.J., and Neil T Carter. 2006. "China's Environmental Governance in Transition." Environmental Politics 15 (02): 149-170.

Moore, Jason W. 2017. "The Capitalocene, Part I: On the Nature and Origins of Our Ecological Crisis." The Journal of Peasant Studies 44 (3): 594-630. https://doi.org/10.1080/ 03066150.2016.1235036.

Neuman, William Lawrence. 1991. Social Research Methods: Qualitative and Quantitative Approaches. Boston, MA [etc.]: Allyn and Bacon. http://eur.summon.serialssolutions. com/2.0.0/link/0/eLvHCXMwY2AwNtIzOEUrE8zSOtKASSXFOiDRJNXcOizZ2Nwyydw gzTAFiMzBd08gDuTjQZRfbkIMTK15ogwybq4hzh66qaVF8dBhjXgDS2Br3MIMWNJMfAmgpaD55 WAt421SDAoWKalpZgB5YDVvaVJakpqYqplqmmiiZFhqqU50 NWWADRIKm4.

Oi, Jean C. 1992. "Fiscal Reform and the Economic Foundations of Local State Corporatism in China." World Politics 45 (1): 99-126. https://doi.org/10.2307/2010520.

Oi, Jean C., Kim Singer Babiarz, Linxiu Zhang, Renfu Luo, and Scott Rozelle. 2012. "Shifting Fiscal Control to Limit Cadre Power in China's Townships and Villages." China Quarterly, 211: 649-675. https://doi.org/10.1017/S0305741012000823.

Overbeek, Winfridus, Markus Kröger, and Julien-FranÇOis Gerber. 2012. An Overview of Industrial Tree Plantation Conflicts in the Global South. Conflicts, Trends, and Resistance Struggles. EJOLT Report No. 3. Available at: www.ejolt.org/reports.

Oya, Carlos. 2013. "Methodological Reflections on 'land Grab' Databases and the 'Land Grab' Literature 'Rush'.” Journal of Peasant Studies 40 (3): 503-520. https://doi.org/10. 1080/03066150.2013.799465.

Robbins, Paul. 2012. Political Ecology: A Critical Introduction. 2nd edn. Oxford: Blackwell.

Rozelle, Scott. 1994. "Decision-Making in China's Rural Economy: The Linkages between Village Leaders and Farm Households." The China Quarterly, 137: 99-124.

Rozelle, Scott, and Guo Li. 1998. "Village Leaders and Land-Rights Formation in China." American Economic Review 88 (2): 433-438. http://www.jstor.org/stable/pdfplus/116962. pdf?acceptTC=true.

Sargeson, Sally. 2004. "Full Circle? Rural Land Reforms in Globalizing China." Critical Asian Studies 36 (4): 637-656.

- 2013. "Violence as Development: Land Expropriation and China's Urbanization." Journal of Peasant Studies 40 (6): 1063-1085. https://doi.org/10.1080/03066150.2013. 865603.

Sayer, Andrew. 2010. Method in Social Science: A Realist Approach: Revised Second Edition. Abingdon: Routledge. https://doi.org/10.4324/9780203850374.

Schneider, Mindi. 2015. "What, Then, Is a Chinese Peasant? Nongmin Discourses and Agroindustrialization in Contemporary China." Agriculture and Human Values 32 (2): 331-346. https://doi.org/10.1007/s10460-014-9559-6. 
2017. "Dragon Head Enterprises and the State of Agribusiness in China" Journal of Agrarian Change, 17 (1): 3-21. https://doi.org/10.1111/joac.12151.

Scoones, Ian, Ruth Hall, Saturnino M Borras Jr, Ben White, and Wendy Wolford. 2013. "The Politics of Evidence: Methodologies for Understanding the Global Land Rush." Journal of Peasant Studies 40 (3): 469-483. https://doi.org/10.1080/03066150. 2013.801341.

Scoones, Ian, Nelson Marongwe, Blasio Mavedzenge, Felix Murimbarimba, Jacob Mahenehene, and Chrispen Sukume. 2012. "Livelihoods after Land Reform in Zimbabwe: Understanding Processes of Rural Differentiation." Journal of Agrarian Change 12 (4): 503-527. https://doi.org/10.1111/j.1471-0366.2012.00358.x.

Siciliano, Giuseppina. 2013. The Social and Environmental Implications of Urbanization Strategies and Domestic Land Grabbing in China. The Hague: The Land Deal Politics Initiative.

2014. "Rural-Urban Migration and Domestic Land Grabbing in China." Population, Space and Place 20 (4): 333-351. https://doi.org/10.1002/psp.1830.

Sikor, Thomas. 2011. Financing Household Tree Plantations in Vietnam: Current Programmes and Future Options. Bogor: Center for International Forestry Research (CIFOR).

So, Alvin Y. 2007. "Peasant Conflict and the Local Predatory State in the Chinese Countryside." Journal of Peasant Studies 34 (3-4): 560-581. https://doi.org/10.1080/ 03066150701804583.

Spoor, Max. 2007. "Growth and regional inequality in Asia's "New Dragons": China and Vietnam compared." In Dragons with Clay Feet? : Transition, Sustainable Land Use, and Rural Environment in China and Vietnam, edited by M. Spoor, N. Heerink, and F. Qu. Lanham, MD: Lexington Books, pp. 83-107.

Spoor, Max. 2012. "Agrarian Reform and Transition: What Can We Learn from 'the East'?" Journal of Peasant Studies 39 (1): 175-194.

Spoor, Max, and Murat Arsel. 2013. "Local Climate Change and Water Distribution in Xinjiang." In Local Climate Change and Society, edited by M A Mohamed Salih, 74-89. London : Routledge.

StoraEnso. 2016. "Progress Book", In Stora Enso's Annual Report 2015. Helsinki: Stora Enso.

Susan, Paulson, and Lisa L. Gezon. 2005. "Politics, Ecologies, Genealogies." In Political Ecology across Spaces, Scales, and Social Groups, edited by Paulson Susan and Lisa L Gezon, 17-37.

Toit, Andries du. 2009. "Adverse Incorporation and Agrarian Policy in South Africa." Cape Town.

(UNDP), United Nations Development Programme. 2012. "Stora Enso Guangxi Forest and Industrial Project Summary Integrated Environmental and Social Impact Analysis Final Report."

Unger, Jonathan. 2002. The Transformation of Rural China. New York: ME Sharpe, https:/ doi.org/10.4324/9781315292052.

van der Ploeg, Jan Douwe. 2009. The New Peasantries: Struggles for Autonomy and Sustainability in an Era of Empire and Globalization. Earthscan. New York: Earthscan. https://doi. org/10.4324/9781849773164.

van der Ploeg, Jan Douwe, 2013. Peasants and the art of farming: A Chayanovian manifesto. Winnipeg: Fernwood.

Walker, Kathy L. 2006. '“Gangster Capitalism' and Peasant Protest in China: The Last Twenty Years.” Journal of Peasant Studies 33 (1): 1-33. https://doi.org/10.1080/0306615 0600624413. 
Walker, Richard, and Daniel Buck. 2007. "The Chinese Road." New Left Review 46: 39 .

Walsh, Isabelle, Judith A. Holton, Lotte Bailyn, Walter Fernandez, Natalia Levina, and Barney Glaser. 2015. "What Grounded Theory Is...A Critically Reflective Conversation Among Scholars.” Organizational Research Methods 18 (4): 581-599. https:/doi.org/ $10.1177 / 1094428114565028$.

Watts, Michael J., and Peter D. Little. 1994. Life under Contract: Contract Farming, Agrarian Restructuring, and Flexible Accumulation. Edited by Michael J Watts and Peter D Little. Madison: University of Wisconsin Press.

Webber, Michael. 2008. "The Places of Primitive Accumulation in Rural China." Economic Geography 84 (4): 395-421.

Weber, M. 1948. "Essay on Bureaucracy." In Weber M. Essays in Sociology, edited and translated by HH Gerth and C Wright Mills, Oxon: Routledge.

Weis, Tony. 2010. "The Accelerating Biophysical Contradictions of Industrial Capitalist Agriculture." Journal of Agrarian Change 10 (3): 315-341.

Wen, Tiejun. 2012. "Xiandaihua Weiji Yu Zhongguo Xin Nongcun Jianshe [Crisis of Modernization and New Countryside Construction in China]." Sannong Zhongguo. Available at: http://www.snzg.net/article/2012/0901/article_29749.html.

White, Ben, Saturnino M. Borras Jr, Ruth Hall, Ian Scoones, and Wendy Wolford. 2012. "The Journal of Peasant Studies The New Enclosures: Critical Perspectives on Corporate Land Deals." The Journal of Peasant Studies 39 (September): 3-4. https://doi.org/ 10.1080/03066150.2012.691879.

Woodhouse, Philip. 2010. "Beyond Industrial Agriculture? Some Questions about Farm Size, Productivity and Sustainability." Journal of Agrarian Change 10 (3): 437-453.

WorldBank. 1988. "China - State Farms Commercialization Project." World Development Sources. Washington, DC. http://documents.worldbank.org/curated/en/1998/03/693672/ china-state-farms-commercialization-project.

Yan, Hairong, and Yiyuan Chen. 2015. "Agrarian Capitalization without Capitalism? Capitalist Dynamics from Above and Below in China." Journal of Agrarian Change 15 (3): 366-391. https://doi.org/10.1111/joac.12121.

Yan, Hairong, Yiyuan Chen, and Hok Bun Ku. 2016. "China's Soybean Crisis: The Logic of Modernization and Its Discontents." The Journal of Peasant Studies 43 (2): 373-395. https://doi.org/10.1080/03066150.2015.1132205.

Ye, Jingzhong. 2015. "Land Transfer and the Pursuit of Agricultural Modernization in China." Journal of Agrarian Change 15 (3): 314-337. https://doi.org/10.1111/joac. 12117.

Ye, Jingzhong, Chunyu Wang, Huifang Wu, Congzhi He, and Juan Liu. 2013. "Internal Migration and Left-behind Populations in China." Journal of Peasant Studies 40 (6): 1119-1146. https://doi.org/10.1080/03066150.2013.861421.

Zhang, Forrest. 2010. "Reforming China's State-Owned Farms: State Farms in Agrarian Transition." In Asian Rural Sociology Association International Conference, 365-378. https://ink.library.smu.edu.sg/soss_research/1089.

Zhang, Lei, Guizhen He, Arthur P.J. Mol, and Xiao Zhu. 2013. "Power Politics in the Revision of China's Environmental Protection Law." Environmental Politics 22 (6): 1029-1035.

Zhang, Qian Forrest. 2012. "The Political Economy of Contract Farming in China's Agrarian Transition." Journal of Agrarian Change 12 (4): 460-483. https://doi.org/10. $1111 /$ j.1471-0366.2012.00352.x. 
Zhang, Qian Forrest, and John A. Donaldson. 2010. "From Peasants to Farmers: Peasant Differentiation, Labor Regimes, and Land-Rights Institutions in China's Agrarian Transition." Politics $\mathcal{E}$ Society 38 (4): 458-489. https://doi.org/10.1177/0032329210 381236.

Zhang, Qian Forrest, Qingguo Ma, and Xu. 2004. "Development of Land Rental Markets in Rural Zhejiang: Growth of off-Farm Jobs and Institution Building." China Quarterly, no. 180: 1050-1072. https://doi.org/10.1017/S0305741004000748.

Zinda, John Aloysius, Christine J. Trac, Deli Zhai, and Stevan Harrell. 2017. "DualFunction Forests in the Returning Farmland to Forest Program and the Flexibility of Environmental Policy in China." Geoforum 78: 119-132. https://doi.org/10.1016/ j.geoforum.2016.03.012. 